\title{
Proteomic Profile
}

National Cancer Institute

\section{Source}

National Cancer Institute. Proteomic Profile. NCI Thesaurus. Code C97139.

A data set that both identifies all the proteins and quantifies the levels of their expression

in a biological sample or specimen. 